https://doi.org/10.15407/frg2019.06.463

UDK 575.224.42+575.224.46: 504.054

\title{
PECULIARITIES OF THE MECHANISMS OF SPONTANEOUS, AND INDUCED BY IONIZING RADIATION AND CHEMICAL FACTORS MUTAGENESIS
}

\author{
V.V. MORGUN ${ }^{1}$, R.A. YAKYMCHUK ${ }^{1}$, I.V. AZIZOV ${ }^{2}$ \\ ${ }^{1}$ Institute of Plant Physiology and Genetics, National Academy of Sciences of \\ Ukraine \\ 31/17 Vasylkivska St., Kyiv, 03022, Ukraine \\ e-mail: peoplenature16@gmail.com \\ ${ }^{2}$ Institute of Molecular Biology and Biotechnologies, National Academy of Sciences \\ of Azerbaijan \\ 11 Izzat Nabiyev St., Baku, AZ 1073 \\ e-mail: ibrahim.azizov47@gmai.com
}

The literary data concerning specific aspects of the mechanisms of spontaneous and induced mutagenesis were reviewed. Their studying will allow to broaden conception about the role of mutations in species formation and evolution of the organic world and will also make it possible to predict the intensity and nature of mutation changes in natural populations of technogenic polluted areas. Three different approaches as to the nature of occurrence of spontaneous point mutations are emphasized: tautomer hypothesis; ionization mechanism; the approach which operates incorrect pairs of DNA bases in a main, canonic tautomer form as a source of mutation. It is stated that a chemical-physical property of incorrect pairs of DNA bases with Watson-Crick and wobble-architectures, which is connected with the controlling of highly stable transitive pairs, is a new key to the understanding of the nature of spontaneous point mutagenesis. The conditions which ensure the realization of primary damages of DNA in mutation are discussed. A special role is played by the efficiency of reparation processes which is different when amounts of dose mutagen load are different. The evidence is presented that prove the increase of mutation frequency, resulted from abrupt changes of the environmental conditions, which cause the activation of nucleotide sequences, which do not code proteins, mobile genetic elements of different classes and sequences which correspond to small RNA. The mechanisms of induced mutagenesis under the impact of high and low doses of ionization radiation and chemical mutagens were described. It has been shown that non-target effects, induced by radiation with a small energy linear transfer, are associated with the formation of genotoxic compounds and the weakening of the rate of DNA reparation processes. Chemical mutagenic factors induce the increase of frequency and disorders of DNA molecules, what is caused by high affinity between chemical mutagens and structures of genetic material. Chemical mutagens at low and moderate concentrations can induce high frequency of point mutations and a low level of chromosome reconstructions; at high concentrations they show radio-mimetic properties. Further studying of the mechanisms of spontaneous mutagenesis and genetic response of biological systems to external stresses will enable the search for new 
mutagenic factors which will cause a high level of organism variability directed by a plant-breeder, and will help identify the ways how to avoid their negative genetic consequences in case of they ingress into environment.

Key words: mutagenesis mechanisms, spontaneous and induced mutations, reparation systems, primary damages of DNA, non-target effects.

Mutagenesis is the process of occurrence, formation and realization of heritable disorders - mutations. A mutation process is a required condition for evolution, and mutations are the only source of genetic variability. A certain level of mutation changes in a biosystem is maintained by a balance of two processes: rate of mutagenesis and the reparation efficiency of DNA disorders. It was assumed that spontaneous mutagenesis was selected by evolution as a positive quality, as it is due to the occurrence of new mutations that cells acquire the ability to survive in unfavorable conditions, i.e., the level of spontaneous mutagenesis undergoes the effect of natural selection which explains the hypothesis about «mutability as an adaptive feature of a species» [50]. Mutation changes give dynamic and elastic properties to genome, and a set of mutations in this or that population is the material for natural selection in changeable environmental conditions which ensures the possibility for a species to survive [16]. The increase of the number and spectrum of mutagenic factors, resulted from technogenic contamination of the environment, causes the increase of mutation changes frequency in populations, and in turn the increase of genetic load and the decrease of population adaptability. When technogenic load in the form of mutagens of chemical, physical and biological nature increases, available systems of DNA damages reparation cannot provide a stable level of spontaneous mutation variability, and the term «spontaneous mutations» loses its sense to be used on large anthropogenically polluted areas [36]. Thus, the studying of the mechanisms of spontaneous and induced mutagenesis will make it possible to widen the idea of the role of mutations in species formation and evolution of the organic world, as well as to predict the intensity and nature of mutation changes in natural populations of technogenic polluted areas.

The formation of the idea of the mechanisms of spontaneous mutations occurrence. The discovery of induced mutagenesis which enabled to artificially change the speed of a mutation process made it possible to study its mechanisms. One of the first hypotheses about the reasons of mutation occurrence consists in the fact that the main source of spontaneous mutations is a natural radiation background. However, the research and calculations have shown that the dose received from the natural radiation background cannot provide available frequency of spontaneous mutation occurrence [28]. According to independent calculations of N.V. TimofeevRessovsky, V.P. Yefroimson and H. Muller, it has been shown that the occurrence of only $1 / 1200-1 / 500$ share of all spontaneous mutations is connected with it one [15]. By nature itself, even if to assume that there are no external effects, gens have to undergo changes with frequency which corresponds to the level of their stability. These changes occur due to the errors of enzyme functioning which ensure the processes of replication, reparation and recombination. 
In 1935, based on the research of radiation mutagenesis in a fruit fly, N.V. Timofeev-Ressovsky, K. Zymmer and M. Delbruk developed a theory of impact according to which mutations occur in two ways: during occasional fluctuation of atoms or as a result of getting the energy from outside [28]. A theory of a gene structure which was based only on its physical-chemical properties without considering biological functions was developed. Taking into account the fact that in further research of mutation induction not all experimental data were explained in the theory of impact [19], M.E. Lobashev in the 1940ties made first assumptions about the existence of premutation (primary) damages of genetic material and the relation between mutagenesis and reparation processes. According to the works of D.N. Nasonov and V.E. Aleksandrov [22], and to M.E. Lobashev's experimental data, the latter formed a physiological hypothesis of a mutation process [19]. External effects which favor mutation induction, being different by nature, though most likely influence a mutation process. It is possible to assume that different mutagens can affect heritable material in a similar way, and non-specific cell damages are the basis of a mutation process [15]. It has become clear that mutation occurrence is a complicated physiological process as a result of which the formation of mutations occurs due to DNA reparation with damages by a principle of non-identical recovery.

Current ideas about the reasons for the occurrence and formation of mutations were established in the 1960ties and they appeared due to the mastering of the technique of induced mutagenesis, decoding of DNA structure, discovery of a reparation system, replication and recombination of genetic material. According to a present-day theory of mutation process mutations occur in three stages: 1) the formation of primary molecular damages in a chromosome; 2) the occurrence of a premutation state which results from DNA structure change; 3 ) the fixation of a potential change into mutation [21]. Primary DNA damages which are temporary modifications of genetic material occur spontaneously as a result of a natural chemical instability of DNA molecules or under the effect of ultraviolet or ionization radiation, reactive oxygen species, metabolic intermediate products, exogenous chemical substances, as well as due to the errors during replication and non-identical reparation, and other exogenous and endogenous factors [43].

The nature of primary DNA damages occurrence and the ways of its realization in mutation. Mutagenesis at the level of gene mutations is a process of the formation of heritable changes which are a quantum, discrete transition of a gene from one state into another. Very different changes in a complicated linear structure of gene are in the basis of such transitions. Those are nucleotide changes, their addition or losses, group rearrangements. «The length» of mutation can vary from one to a few tens of nanometers, but when disorders are more massive this length can increase by several times. Molecular mechanisms of the interaction of many mutagenic factors with DNA have been studied well, and the disorders which occur alongside have been identified. The mechanisms of mutation induction due to the errors of reparation, replication, and recombination have been studied less. 
Numerous spontaneous disorders of DNA constantly occur in the cells of eukaryote (single-strand gaps, apurinization, base damages etc.) which is $8 \cdot 10^{3}$ per hour or about 130 per minute [38]. However, the observed mutation speed is much lower than the expected one at such a high damage level. In bacteria genes it is $10^{-8}-10^{-10}$ per cell division, and in mammals it is $10^{-5}-10^{-6}$ per gamete [55]. It proves that only a small part of primary damages is turned into heritable changes, whereas up to $90 \%$ of primary DNA damages are removed completely by reparation systems.

Both nitrous bases and sugar-phosphate frame of DNA can be damaged. DNA nitrous bases can be modified by means of deamination, methylation, formation of adducts and pyrimidine dimers. When sugarphosphate frame is damaged, single- and double-strand gaps occur as well as cross-links of DNA chains [43]. DNA primary damages break matrix processes, making replication of genetic material and expression of genetic information more complicated. They can decrease the accuracy of replication, serve as signals to start a reparation system, a serious stage of which is homological and non-homological recombination; they can to cause the cessation of cell divisions [43], to speed up the processes of senescence, to cause cancer diseases [37, 53].

There are three different approaches in literature to the nature of the occurrence of spontaneous point mutations: tautomer hypothesis, which envisages a principle of point mutagenesis in the transition of DNA bases from the main into rare form, so-called a mutagen tautomer form; ionization mechanism [45], which brings a principle of mutation to occasional ionization (protonation or deprotonation) of DNA bases; and the approach which operates incorrect pairs of DNA bases in the main, canonic tautomer form as a source of mutation [48].

At present there are all grounds to believe that the main reason for spontaneous mutagenesis is oxidant damages of DNA bases that occur due to the interaction with reactive oxygen species which are formed in the processes of cell metabolism. In aerobic organisms in a respiration process 4-5\% of molecular oxygen is transformed into its reactive forms which have mutagenic properties: superoxide anion $\left(\mathrm{O}_{2}^{-}\right)$, hydrogen peroxide $\left(\mathrm{H}_{2} \mathrm{O}_{2}\right)$, hydroxyl radicals $\left(\mathrm{OH}^{-}\right)$and singlet oxygen $\left({ }^{1} \mathrm{O}_{2}\right)$ [23]. 8-Hydroxyguanine, which pairs with adenine and causes transversion $\mathrm{G}: \mathrm{C} \rightarrow \mathrm{T}: \mathrm{A}$, occurs most frequently among modified bases. Besides, as well as many other modified nucleotides, it can be connected into DNA from an intercellular pool of modified dezoxynucleotide triphosphates, being paired with cytosine or adenine, causing both $\mathrm{G} \rightarrow \mathrm{T}$ and $\mathrm{A} \rightarrow \mathrm{C}$. Oxidation of pyrimidine bases in DNA goes with the formation of mutagenic 5-hydroxycytozine, 5-hydroxyuracil and uracil glycol which pair mostly with adenine and cause $\mathrm{C} \rightarrow \mathrm{T}$ transitions. The last adducts are the products of oxidative deamination of cytosine [7].

Endogenous alkylating agents add a lot to spontaneous mutagenesis: $\mathrm{S}$-adenozyl metionine, betaine and choline. Thus, it is assumed that S-adenozyl metionine may generate the formation of about 4000 molecules of 7-methyl guanine, 600 molecules of 3-methyl adenine and 10-30 molecules of $\mathrm{O}^{6}$-methyl guanine in every cell of an animal within 24 hours. The first two adducts destabilize glycoside bonds, which provides the formation 
of apurinic sites. The last adduct is highly mutagenic and causes the formation of $\mathrm{GC} \rightarrow \mathrm{AT}$ and $\mathrm{TA} \rightarrow \mathrm{CG}$ transitions. Other numerous alkylated derivatives of DNA nitrous bases which are formed in vivo are known [23].

Presently 12 key incorrect pairs of DNA bases are known which, in the process of thermal fluctuations, easily acquire enzymatic-competent conformation in a sufficient water-repellent pocket of recognition of highly-point replicative DNA-polymerase: $A \cdot C^{*} / C^{*} \cdot A, G^{*} \cdot T / T \cdot G^{*}, G \cdot A_{\text {syn }}$, $A^{*} \cdot G^{*}{ }_{\text {syn }}, A^{*} \cdot A_{\text {syn }}, G \cdot G^{*}{ }_{\text {syn }}, C \cdot T / T \cdot C, C \cdot C^{*}$ and $T \cdot T^{*}$ (an asterisk marks mutant tautomers). Alongside with them, so-called long Watson-Crick incorrect pairs of DNA bases $A \cdot G / G \cdot A, G \cdot G^{*}$ and $A \cdot A^{*}$ also play an important role [7]. It is due to their participation, that enzymatic-competent incorrect pairs of DNA bases $G \cdot A_{\text {syn }}, A^{*} \cdot G^{*}{ }_{\text {syn }}, A^{*} \cdot A_{\text {syn }}$ and $G \cdot G^{*}{ }_{\text {syn }}$ are formed through proper non-dissociative conformational transition.

Contrary to a common theory that mutant tautomers of bases are formed regardless of a «complementary» partner-base in the interaction in an incorrect pair, O.O. Brovarets and D.M. Hovorun [7] support another, principally different approach. The approach is based on internally-characteristic ability of base pairs (both correct and incorrect ones) with Watson-Crick architecture of $\mathrm{H}$-biding to transfer by double proton transition in wobble-mismatch and backwards. A characteristic physicalchemical peculiarity of these tautomer transitions is the fact that all of them, without any exception, are controlled by highly stable $\left(\Delta E_{\text {int }}>100\right.$ $\mathrm{kcal} /$ mole) transitive conditions - close ion pairs of (proton base) (deprotone base) type [46]. It is assumed that it is this physical-chemical property of incorrect pairs of DNA bases with Watson-Crick and wobble-architectures that is a new, productive key to the understanding of the nature of spontaneous point mutagenesis [7].

Hence, depending on the type of DNA damages and the stage of a cell cycle primary damages, one of the several reparation ways can be directed: during reparation damages are either removed accurately, in this case primary structure and DNA succession are totally restored; or damages turn into gene mutations or result in chromosome aberrations in case of non-identical reparation. Thus, primary damages are the damages of chemical structure of DNA molecule, and mutations are the changes of succession or number of DNA which occur as a result of non-identical DNA reparation from primary damages.

Cell systems of control over mutation occurrence. In the conditions of a natural mutation process, «internal» mutagenesis plays the main role in the occurrence of evolutionary innovations, which, contrary to «external» induced mutagenesis, does not have an occasional, uncertain character; instead it is regulated by certain principles which are the basis of photogenetic transformations or the mechanics of the development in ontogenesis. In addition, a serious difference in the variability of some genetic loci of higher organisms, namely a mouse and man, were identified [23], the participation of HSM3 and HSM6 genes in the control over a mutation process in yeasts was proved (S. cerevisiae) [31, 42]. Data of this type gives grounds to assume that frequency of spontaneous mutation occurrence in some eukaryotic loci can be genetically deterministic.

As chromosomes are protected by a nuclear membrane, the attack of nuclear DNA with free radicals, formed in cytoplasm, can be less effective. 
So, the main inductor of a cytogenetic effect is malonic dialdehyde which is formed by a lipid layer of a nuclear membrane and cause the formation of gaps and additional pores; and organic components which have clastogene activity penetrate though them (the latter) [10]. The reason for the appearance of chromosome reconstructions is associated with the cutting of modified bases with DNA-glycosylase during excision reparation and further formation of AP-sites, and under optimal conditions their lifetime may be up to 190 hours [49]. AP-sites lead to the cessation of a replication fork and they must be removed to avoid cell death. When AP-sites are removed, single-strand gaps which stimulate two-strand gaps and recombination occur [39]. Two-strand gaps can cause losses of chromosomes or their sites, and gene mutations and chromosome reconstruction may occur in case of wrong DNA reparation with two-strand gaps with help of recombination reparation or direct connection of the ends.

According to the current understanding of polyploidy it is not a simple genome fusion; instead it contains a whole spectrum of moleculargenetic processes and it is a very important source of genetic variability. It is a known fact that, as a rule, multivalent chromosome complexes are formed in polyploids in a prophase of the first meiosis division, unlike bivalent complexes in diploids. Further crossing-over between homological chromosomes and chromosome division between daughter cells are broken under such conditions. Fast losses of certain genes and specific inactivation of other genes due to methylation are recorded in model polyploids. It is assumed that epigenetic silencing can protect duplicated copies from becoming pseudogenes, and in this way it helps them get new functions [56]. These and other changes of a genetic apparatus cause heritable variability of the expression of morphological, anatomical, cytological, physiological, biochemical and other features and properties of plant organisms, all this eventually gives quite a varied initial material to expand gene pool for breeding of new cultivars [6].

There are some grounds to assume that a chromatin structure in general and geterochromatin plots in particular are very important in the change of gene expression as they can constitute from $20 \%$ to $90 \%$ of genome. A total DNA content in a haploid set of chromosomes of eukaryotic organisms of various species differs by more than 200 times [23]. It is assumed that redistribution of heterochromatin takes place due to mobile genetic elements which «pull» fragments of heterochromatin DNA to various genome cells, and it results in Goldschmidt mutations. The relocations of this type most likely favor mass formation of various inversions and translocations which usually go along with speciation. The evolution process of extraneous genetic material in a cell ends with designing new highly molecular genetic structures - pekelasomes which enter in recombination acts with cell DNA. Sometimes new microchromosomes are formed on the basis of pekelasomes or they integrate with host chromosomes and become part of a cell genome.

At the current stage of the development of general and molecular genetics classical understanding about heritable variability changes drastically and it is based on an uncontrolled stochastic mutation process [17]. The results of the numerous researches confirm the existence of structured driving forces and systems of the control over genome reconstructions. 
Such systems include nucleotide sequences which do not code proteins, namely, repeated DNA sequences, mobile genetic elements (MGEs) of different classes and also some newly-discovered sequences which correspond to small RNA. There is the opinion that mentioned-above systems can get activated as a result of abrupt changes of the environment or internal medium and they can cause a serious increase of frequency and expansion of mutation spectrum as the material for selection and further adaptation of the object to new conditions for a short period of time [16].

MGEs are spread everywhere and they constitute a considerable part of genome DNA of many studied organisms. For example, maize genome contains $50 \%$ of MGEs, $20 \%$ of MGEs are in a fruit fly's genome, and man's genome enumerates over $4 \mathrm{mln}$ separate copies when the total MGEs content is $30-45 \%$. Moving randomly, MGEs influence the structure of host genetic material considerably and have a fundamental significance in the formation of genetic variability. R.B. Hesin believes that transposition activity of MGEs causes $80 \%$ of spontaneous mutations and it is the main reason for their occurrence. MGE transposition activity changes under the effect of mutagen factors, DNA gaps occurrence and its (DNA) methylation [30]. According to S.M. Hershenzon's hypothesis, a fragment of extraneous DNA integrates to genome and acquires the properties of a mobile element or activates host mobile elements, or both processes take place [17]. Numerous examples of natural mutability caused by MGEs mutagen activity confirm this assumption. One can mention a big evolution role of DNA-containing elements which in fact exercise genetic engineering in nature, taking part in the transfer of genes and their fragments between two remote organisms and also in the control over the rates of a mutation process. The opinion exists that due to MGEs gene pools of all organisms are united in a general gene pool of living nature [47].

Special attention is paid to the participation of constantly circulating viruses in the environment in a spontaneous mutation process which, causing various types of an infectious process, change the sensitivity of cell genome to the factors of various nature. Two ways of mutation induction are considered in the process of studying a mutagen effect of DNA-containing viruses: 1) the expression of the introduced and integrated genes and the effect of synthesized products of these genes on metabolism of cell DNA of recipients; 2) the integration of exogenous nucleotide sequences with cell DNA of a recipient and the induction of MGE transpositions; 3 ) the inhibition of the cells with exogenous DNA and modified bases of reparation cell enzymes which helps identify a mutagen effect [21]. One of the hypotheses concerning the mechanism of mutagen effect of DNA-containing viruses is that more replicators and more such damages as singlestrand gaps are initiated in the cells with a reduced S-phase under the effect of T-antigens as compared with the cells with a longer replication period. The appearance of a larger number of points of the replication beginning may result in the errors frequency increase under DNA synthesis which are realized into chromosome gaps and gene mutations.

Mechanisms of the genetic disorders occurrence under the effect of ionizing radiation. The issue of induced mutagenesis has always been one of the most urgent problems of biology. The relevance of the research of mutation process and its mechanisms is explained by a serious worsening 
of the environmental conditions due to anthropogenic pollution in the whole world, including different regions of Ukraine. The effect of the environmental factors which can enhance a mutation process in live organisms grows constantly [36]. The following can be mentioned among them: nanotechnologies and nanomaterials, a wide range of physical factors, electromagnetic and ionizing radiation in a range of super low and hyper high waves etc. [27]. As far as genetic activity is concerned, ionizing radiation is the best studied activity which is divided into electromagnetic (X-rays and $\gamma$-rays) and corpuscular radiation (fast, intermediate, slow and thermal neutrons, $\alpha$ - and $\beta$-ray radiation, electrons, protons).

Back in the 1930ties scientists came across a discrepancy between an extremely small amount of cell-absorbed energy of ionizing radiation and a high caused biological effect. At the beginning of the 1920ties, having considered the nature of the interaction of ionizing radiation with a substance, F. Dessauer came to a conclusion that a reaction took place in one of the many irradiated units (cells, gametes, chromosomes etc.) only in the case when one unit got a certain number of hits. This concept is known as «a principle of hit» and «a theory of target» in radiobiology. It has been stated that a primary physical starting mechanism of gene mutations is one hit in the form of single ionization into an effective format with a radius of about $10^{-7} \mathrm{~cm}$; energy transfer to the place of impact without its dissipation lower than a threshold of effect is possible within this format. In the fundamental works of D. Li, K. Zimmer, M. Demerec, M. Delbruck and N.V. Timofeev-Ressovsky radiobiological effects in the aspect of induced mutations were studied on various objects. Damaging effect under ionizing radiation occurs by «all or nothing» principle depending on hit or non-hit of ionizing particles into a unique structure of a living object. A nucleus and chromosomes are the most hit sensitive in a cell [11].

Radiation effect can result from one or several hits of ionizing particles into a target. This will define the nature of «dose-effect» dependence. The consequence of two independent/separate gaps is the appearance of chromatide and chromosome translocations and inversions which result from a connection of fragments. The occurrence of double-hit reconstructions increases proportionally to a dose square [2].

Recent molecular-genetic research has shown that spectra of spontaneous and induced DNA changes differ greatly. If under spontaneous mutagenesis $65 \%$ of DNA changes concern point mutations, then basically microdeletions occur under radiation induced mutagenesis, and the length of DNA plots covered by them can vary - from a part of one gene to several genes [32]. Mechanisms of genetic radiation effects were studied in model experiments which gave the main evidence of the events that took place in radiated DNA. Its damages at a physical-chemical stage of the radiation effect can be realized in two ways. The first one envisages a direct action - electrons which are formed in the process of energy exchange, as a rule, lead to a break of molecular ties of a target, because of this singleand double-strand gaps of DNA molecules occur. Damages of this type depend linearly on ionization density, radiation dose which is characterized with average and high indicators; they have a threshold of action whose size is determined by the degree of reliability of reparation systems [24]. As a result, determinate, non-stochastic radiation damages occur. 
However, another way of the interaction of ionizing radiation with DNA can be more dangerous under low radiation doses (units and tenth parts $\mathrm{sGr}$ ) - an indirect action - when damaged biological agents which are formed in the places of energy exchange of a particle or quantum can migrate for long distances and result in damaging structures-targets. Small doses of radiation cause stochastic, thresholdless effects: malignant formations and genetic damages. One of the main active chemical groups, the number of which increases during the interaction of radiation with a living system, is free radicals - very aggressive agents which damage biologically important molecules and structures. It was confirmed with help of the introduction of various «interceptors» of free radicals in biological objects before their irradiation that a considerable number (60-80 \%) of DNA damages induced by ionizing radiation in vivo with a small energy linear transfer was the result of indirect radiation effect [20]. The number of various DNA damages which are determined per dose unit under its irradiation in a solution (in vitro) is 60-100 times larger as compared with the number of the same damages registered in DNA of irradiated cells (in vivo) [61].

As radiation density decreases cell membranes become sensitive targets. Group $\mathrm{OH}^{-}$is considered to be one of the main agents of free-radical processes of lipid oxidation [24]. Low-intensive continuous radiation causes the reduction of phospholipids in membranes, changes their physical-chemical properties which in turn prevents a regular process of all vital functions including reparation processes. A reverse dependence of lipids peroxide oxidation rate on a radiation dose and its capacity determines a significant role of membranes as a regulation coordinator of oxidation processes as well as radiation nature under the effect of weak damaging factors. The weakening of the rate of DNA reparation processes can be observed under chronic radiation at low doses along with a constant flow of molecular damages: the synthesis of $\alpha$ - and $\beta$-polymerases decreases, the access of reparation enzymes to the damages gets complicated because of insufficient relaxation of heterochromatin, the blockade of transition from cell stage $G_{2}$ to stage $M$ is not activated which leads to the disconnection of reparation of double-strand gaps etc. [18].

Most frequently ionizing radiation damages one strand of DNA. Herewith, such primary damages as deaminized bases, dimerized or hydrated pyrimidine bases etc. are formed. Later, primary damages can either be repaired or lead to the formation of point mutations or chromosome reconstructions [52]. Secondary damages include such local summary damages as multi-site cluster damages, gaps of hydrogen bonds, intraand intermolecular joints and also configuration changes of supermolecular DNA structures. The latter is caused by double-strand DNA gaps which occur if single DNA gaps are located from each other at a distance which is less than $10 \mathrm{bp}$. Under the effect of rarely-ionizing radiation with low ionization density the correlation of double- and single-strand DNA gaps is 1:(20-100). Densely-ionizing radiations cause a significantly larger number of double-strand gaps, due to this fact the correlation of gaps decreases to 1:(4-6). Alongside with this, the number of so-called cluster damages, lethal for plants, increases in spectrum of molecular DNA damages [29].

Among all DNA damages, induced by ionizing radiation, doublestrand gaps are repaired with the lowest speed. The following assumptions 
were made when studying the nature of their formation in DNA molecule: 1) the quality rather than the number of double-strand gaps is important (a hypothesis of a local-numerous damage of a site); 2) when cell irradiation takes place ionizing radiation forms gaps in DNA in the way which differs from the one expected from the experiments with DNA irradiation in vitro. It is connected with the fact that DNA in a cell, interacting with different proteins, forms supermolecular structures of higher orders chromatin, chromosomes. When charged particles move, DNA molecule in chromatin is damaged in «a non-random» way, i.e., heterogeneous distribution of double-strand gaps take place across DNA [3].

Genetic effects of ionizing radiations occur in irradiated cells as a result of DNA damage which is a molecule-target in a cell. However, for the last 30 years the data about non-target effects of radiation was gathered, their studying is closely connected with the problem of genetic sequences of continuous irradiation at lower doses, and this problem has become extremely relevant after the accident at Chornobyl NPP and other local increases of radiation background [59]. These effects are genome instability, bystander effect, adaptive response, hormesis, super sensitivity [35].

Having taken into consideration the results of their own research and having generalized other data, O.B. Burlakova et al. [8] state that ionizing radiation at small and supersmall intensities has a unique ability to increase a biological effect by tens of times. Herewith: 1) the dependence of the effect on a radiation dose has a monotonous, polymodal nature; 2) the doses at which extremums occur depend on power (intensity) of radiation; 3 ) the radiation in small doses lead to the changes (in most cases towards increasing) of sensitivity to the effect of damaging factors; 4) low-intensive radiation is more efficient than acute radiation in some dose intervals. Taking into consideration the results of long-term researches aimed at studying of mutagen activity of radionuclide contamination of soil, water and bottom sediments of water reservoirs in the alienation zone and the zone of mandatory resettlement of Chornobyl NPP which were carried out by the researchers of the Institute of Plant Physiology and Genetics NAS of Ukraine, the scientists established a high mutagenic threat of chronic low-dose radiation for living organisms, caused by the environmental pollution with natural and artificial radioisotopes and a complicated non-linear dose-effect dependence [60].

Major mechanisms and specifics of the effect of chemical mutagenic factors. Mutagenic properties were clearly defined for all types of ionizing radiations. As to chemical compounds only some of them have mutagenic activity, the identification of which is done with great difficulties. It can be explained by, firstly, peculiar features of mutagen effect which have specific-, tissue- and even test-object-specific character, and secondly, a great number of chemical compounds which are real or potential contaminants of the environment [33]. The understanding of the threat of chemical mutagens for man's genetic health - contaminants of the environment came only in the 1960ties thanks to the role of the work of P.E. Conan and H.S. Lanski in which for the first time the fact of induction of chromosome aberrations in blood cells of an individual affected by yperite was proved [1]. I.A. Rapoport was the first scientist who spoke about the threat of the uncontrolled use of chemical mutagens for the environment. Taking 
into account the fact that chemical mutagenesis, as a highly effective method, is widely used in agricultural plant breeding, and xenobiotics, when they enter the environment, are a genetic threat for living organisms, it becomes of great importance to study the major mechanisms and specifics of the effect of chemical mutagens.

The division of chemical compounds into mutagens or modifiers is based on a size of their dipole moments. They are 2.4-2.7 D (Debye) in chemical mutagen substances and they range from 4D and higher in modifiers. Dipole moments of the molecules of chemical mutagen substances appear to correspond to dipole moments of certain molecular structures of a cell which include triplets, nucleotides, and amino acids - predecessors of DNA and protein synthesis [25]. The connection of chemical mutagens with certain structures of genetic material of a cell and some plots - chromosome loci - is associated with this.

The consequences of the effect of chemical mutagens and ionizing radiation differ. When the last group leads mainly to a structure break of the very chromosomes (fallout, insert, replacement of large DNA fragments) which decreases viability of the treated material immensely, then the first group penetrates into a cell, reaches its nucleus and reacts with atoms which form a DNA molecule, damages its chemical structure causing mainly point mutations - a change of DNA nucleotide pairs (replacements, inserts or fallout) [12]. Chemical mutagens, as compared with radiation ones, have a better action and sensitivity control and form a much wider spectrum of genetic changes [1]. I.A. Rapoport believed that chemical mutagens and supermutagens have a potential for actions, typical only for them, which is associated with their three properties: 1) high intensity which exceeds a mutagen effect of short-wave radiation by hundreds and thousands times; 2) excellent action control which exceeds not only physical mutagens but also potentials of spontaneous natural mutations; 3) chemical mutagens and supermutagens differ in high specificity which is expressed by narrow spectra in some cases but they include quite a large and valuable set of positive features [12].

At present a list of chemical mutagens enumerates tens of substances by the number of main functional centers and tens of those calculated on their derivatives. Alongside with this, new data about the mechanism of a mutagen effect is accumulated, so their systematization, caused by the peculiarities of a chemical structure, the interaction with genetic material, the diversity of a biological effect, creates certain difficulties [13]. There are three main groups of chemical mutagens in the most widely accepted classification [2]: inhibitors of nucleic acid predecessors synthesis (enzymes which synthesize DNA components); analogs of nitrous bases: nitro- and nitrozocompounds (nitrous acid, nitrozamines, nitrozamides); alkylating agents (iodoacetamide, isopropyl bromide, diazoalkanes, ethers of sulfuric, phosphoric, nitric acids and alkansulfo acids; 2-chloretylamine, ethyleneimine and their derivatives) - at present they all are considered to be the strongest among all the identified ones; oxidants, deoxidizers, free radicals (free forms of oxygen, nitrates, nitrites); pesticides (herbicides, fungicides; acridine pigments (proflavin, acridine orange).

When acting alkylating mutagens in low doses are used most efficiently, the reaction of alkylation (methylation) of DNA bases is observed. 
Euchromatine-heterochromatine correlation may change towards the increase of the amount of heterochromatine [34]. A chemical mutagen in high concentrations directly effects on chromosome heterochromatine in the area of centromere which causes chromosome lagging in a mitosis anatelophase [33]. The advantage of chemical compounds in low and moderate concentrations, as compared with radiation, is high frequency of point mutation induction and a low level of chromosome reconstructions $[54,58]$. However, chemical mutagens in high concentrations have a completely opposite effect, inducing the damage of a cell nucleus apparatus in the form of chromosome and aneuploidy reconstructions which corresponds to a severe effect of ionizing radiations. Considering the specificity of chemical mutagens effect mechanisms connected with the correlation of dipole moments of their molecules and dipole moments of certain cell molecular structures - predecessors of DNA and protein synthesis, the advantageous type of genetic material disorders is mutations of separate chromosome loci [41]. The formation of such conceptions is based on the results of the studying of alkylating compounds mutagen activity in low and moderate concentrations. It is under these conditions that one can expect the induction of point mutations of high frequency and chromosome aberrations of a low level which makes the wide use of chemical mutagens in breeding practice more advantageous and resultant. Probably, in high concentrations, as it is shown in the example of N-nitroso-N-methyl urea, there is no relationship between chemical mutagen and cell genetic structures and mutagen acts randomly by a principle of a target [51]. The phenomenon of a chemical mutagen effect in high doses is classified as radiomimetic.

Any molecule of a chemical mutagen which concentration is different from zero has a finite probability to induce mutations. However, the doseeffect dependence for chemical mutagens, as a rule, appears to be significantly non-linear. One of the reasons of the linearity distortion of dose dependence is connected with the ambiguity indicator between primary DNA damages and gene or chromosome mutations which occur because of them. The probability of the realization of primary DNA damages in mutation depends on the efficiency of reparation processes, however the efficiency of these processes appear to be different when values of mutagens load doses are different. Another reason is connected with the process of biotransformation of a chemical mutagen which, most likely, causes the effect of linearity distortion of dose dependence in in vivo system [33]. The xenobiotics biotransformation system contains a large group of enzymes which carry out oxidation, restoration, hydrolysis, dealkylation, acylation and other chemical reactions which lead to metabolic transformations of xenobiotic compounds and their excretion from organism [1]. Hence, to classify chemical mutagenesis as a common treatment of DNA molecule with different mutagens in in vitro conditions is a simplified approach to the understanding of a genetic framework in a living structure.

The target of the chemical mutagen effect in a cell is DNA and some proteins. The latter include main proteins which play a structural role in genome organization or participate in replication, recombination or reparation. A number of mutagens which cause mutations being not covalently connected with DNA. In this case matrix synthesis on DNA takes place 
with errors. The deceleration or even cessation of DNA synthesis occurs under the effect of mutagens which inhibit synthesis of DNA predecessors. It becomes more possible in these conditions that a reaction system of a cell may miss an absent nucleotide or include a wrong one instead. The consequence of these events is mutation [1].

According to the time of the effect on a cell genetic apparatus, chemical mutagens can be classified into two types: those which act on intact DNA, and the ones which are able to cause mutations only during DNA replication. Mutagens of the first type can connect various groups of atoms to nitrous bases and phosphate groups in DNA. After that either coding DNA properties change and transformed bases are built in opposite changed bases during its replication, or a skeleton gap of DNA molecules takes place which, in particular, can lead to the formation of chromosome reconstructions. The second type of mutagens includes different compounds, close or similar to nitrous bases by their structure, and other substances which connect with DNA and in this way prevent its correct replication. Chemical mutagens which are effective mainly during DNA replication and can also have a mutagenic effect on intact DNA are known. The effect of such chemical compounds results in a serious increase of mutation frequency [14].

Several mechanisms of chemical mutagenesis are described in the theory of DNA origin. Thus, a large class of alkylating compounds which includes not only typical alkylating agents (diazoalkanes, ethers of sulfuric acid and alkan sulfoacids) and also phosphoric and nitrous acid ethers, aminoethylating (2-chlorethylamine, ethylamine and their derivatives) and oxyethylating (ethylenoxide and its derivatives) reagents, aldehydes, can carry out alkylation (connection of a methyl group to an ethyl one) of nitrous bases in some positions (most frequently of guanine) or of polynucleotide strand phosphate groups [4]. Alkylated nitrous bases due to hydrolysis split off a DNA chain, and as a result of this apurinic and apyrimidinic sites occur. Later hydrolysis of unstable dezoxyriboside residues can take place in such sites and single-strand gaps in DNA result from it. Gaps can be the result of hydrolysis after phosphate group alkylation [2, 26].

Presently the availability of chemical mutagens in 10 classes of compounds has been identified. They are aromatic cycles, ethers, galogenic aliphatic and aromatic carbohydrates, nitrosamines, phthalic acid ethers, some phenols, polyhchlorinated dyphenyls and aromatic polycycles. Besides, the occurrence of chromosome aberrations is caused by different chemical substances (or changes of their concentrations) which are not mutagens but they disturb a normal cell life (ions of heavy metals, aldehydes, oxidizers, imbalance of essential microelements etc.) which promote mutagenesis $[1,5,9]$. Compounds of heavy metals - cadmium, chrome, nickel, lead, mercury, arsenic etc. - belong to inorganic mutagen compounds which are common in the environment. For instance, cadmium chloride induces chromosome aberrations, micronuclei and sister chromatid exchanges in marrow cells and dominant lethal alleles in the experiments on mice. Similar results were received in the experiments with nickel and chrome compounds [44]. Lead can induce chromosome aberrations, micronuclei and disorders of sister chromatid exchanges in peripheral blood cells [40]. 
Heavy metals can be placed in such order by the ability to induce gene mutations in microorganisms: $\mathrm{As}^{3+}>\mathrm{Pb}^{2+}>\mathrm{Cd}^{2+}>\mathrm{Zn}^{2+}>\mathrm{Cu}^{2+}$, and by the ability to induce chromosome aberrations in cell cultures - in this way: $\mathrm{Zn}^{2+}>\mathrm{Pb}^{2+}>\mathrm{Al}^{3+}=\mathrm{Ni}^{2+}>\mathrm{Cd}^{2+}>\mathrm{Cu}^{2+}$. The studies of mutations induction mechanisms with metal compounds have shown that divalent cations can interact with DNA directly. Most of the authors associate the mechanism of heavy metals genotoxic effect with the initiation of the processes of reactive oxygen species formation in cells, capable of damaging DNA. Besides, the ability of a number of metal compounds to inhibit the activity of many intracellular enzymes can lead to the increase of the errors of reparation systems which ensure the DNA integrity [14].

Theoretical and practical trends are closely intercrossed in chemical mutagenesis, and this connection has been identified very early and mainly because of an extraordinary talent of I.A. Rapoport to predict the application of his findings in the branch. One of the achievements of chemical mutagenesis was the development of about 400 mutant cultivars of agricultural crops by various agricultural and biological institutions in a relatively short period of time (1960-1990). The method of chemical mutagenesis initiated a whole epoch in various spheres of biological science, and it was introduced both in the Soviet Union and in other countries: Hungary, China, Vietnam, India, and the USA [33]. However, there is still one of the unsolved problem of this method which consists in the difficulty to predict in which gene the next mutation will occur and whether it will be positive - adaptive or negative - disastrous. The difficulty, first of all, is predetermined by a degree of randomness of a mutation nanoprocess.

Hence, a spontaneous mutation variability is subordinate to a complicated genetically controlled system of balanced physical-chemical and biological mechanisms, and it is selected by evolution as a positive feature of an organism to acquire the ability to survive in unfavorable environment conditions. Modern ideas about the nature of spontaneous point mutagenesis are based on three different approaches: a tautomer hypothesis, an ionizing mechanism and the approach which operates wrong pairs of DNA bases in the main, canonic tautomer form as a source of mutations. The probability of primary DNA damages realization in mutation depends on the efficiency of reparation processes and it appears to be different when values of mutagen load doses are different. The movement of fragments of heterochromatid DNA into different genome holes together with mobile genetic elements facilitates the mass formation of various inversions and translocations which go along with speciation. Being involved in the structural driving forces and the control systems over genome reconstructions, nucleotide consequences which do not code proteins, mobile genetic elements of various classes, consequences which correspond to small RNA are able to get activated due to different changes of the environment or internal medium and lead to a fast frequency increase and the expansion of mutation spectrum.

A great number of DNA damages induced by ionizing radiation with a small energy linear transfer is a result of non-target effects which is connected with the induction of biological agents that are capable to migrate for long distances and to damage structures-targets and weakening the rate 
of DNA reparation processes. Chemical mutagenic factors which are the components of the global technogenic contamination of the environment induce the increase of frequency and spectrum of DNA molecule disorders that is defined by a high relationship between chemical mutagens and structures of genetic materials and the unpredictability of genetic sequences biotransformation. Chemical mutagens at low and moderate concentrations can induce high frequency of point mutations and a low level of chromosome reconstructions. There is no relationship between a chemical mutagen and its influence on cell genetic structures at high concentrations and the former shows radiomimetic properties. The research of the mechanisms of spontaneous mutagenesis and genetic response of a biological system to external stresses will make it possible to carry out the search of new mutagen factors which will cause a high level of organism variability, well-controlled by a plant breeder, and to identify the ways how to avoid their negative consequences in case entering the environment.

\section{REFERENCES}

1. Abilev, S.K. (2012). Chemical mutagens and genetic toxicology. Priroda, No. 10, pp. 3946 [in Russian].

2. Abilev, S.K. \& Glazer, V.M. (2015). Mutagenesis with the basics of genotoxicology. Moskva; Sankt-Peterburg: Nestor-Istoriya [in Russian].

3. Andreev, S.G., Eydelman, Yu., Hvostunov, I.K., Salnikov, I.V. \& Talyizina, T.A. (2005). Biophysical modeling of radiation damage to the genetic structures of cells. Radiation biology. Radioecology, 45, No. 5, pp. 549-560 [in Russian].

4. Baranov, A.A. \& Albitskiy, V.Yu. (2009). Mortality of the child population of Russia (trends, causes and ways to reduce). Moskva: Pediatr' [in Russian].

5. Bezrukova, M.V., Fathutdinova, R.A. \& Shakirova, F.M. (2016). The protective effect of wheat germ agglutinin on mitosis in the roots of Triticum aestivum seedlings when exposed to cadmium. Fiziologiya rasteniy, 63, No. 3, pp. 382-389 [in Russian].

6. Belko, N.B., Gordey, I.A., Schetko, I.S. \& Gordey, I.S. (2011). The creation of tetraploid forms of winter rye (Secale cereal L.) using nitrous oxide and the genetic effects of genome duplication. Faktory eksperymentalnoi evoliutsii orhanizmiv, No. 10, pp. 15-20 [in Russian].

7. Brovarets, O.O. \& Hovorun, D.M. (2014). Molecular logic of spontaneous point mutagenesis: variation on the theme... Ukrainica Bioorganica Acta, No. 1, pp. 48-55 [in Ukrainian].

8. Burlakova, E.B., Konradov, A.A. \& Maltseva, E.L. (2003). Effect of ultra-small doses of biologically active substances and low-intensity physical factors. Fizicheskaya himiya, 22, No. 2, pp. 4-15 [in Russian].

9. Vergolyas, M.R., Lutsenko, T.V. \& Goncharuk, V.V. (2013). Cytotoxic effect of chlorphenols on cells of the root meristem of the seeds of onion (Allium fistulosum L.). Cytology and Genetics, 47, No. 1, pp. 44-49 [in Ukrainian].

10. Guskov, E.P., Mashkina, E.V., Belichenko, N.I., Varduni, T.V., Volosovtsova, G.I., Pokudina, I.O., Guskov, G.E. \& Shkurat, T.P. (2009). Mutation processes in animals pre-adapted to oxidative stress. Ekologicheskaya genetika, 7, No. 1, pp. 41-48 [in Russian].

11. Davydenko, V.M. (2011). Radiobiology. Mykolaiv: MDAU [in Ukrainian].

12. Ezheva, T.A. \& Shirokova, A.V. (2012). New possibilities of chemical mutagenesis. Priroda, No. 10, pp. 32-38 [in Russian].

13. Efimova, N.V., Rukavishnikov, V.S. \& Zarodnyuk, T.S. (2007). Development of measures to maintain health in the programs of socio-economic development of the Russian Federation. Gigiena i sanitariya, No. 5, pp. 72-74 [in Russian].

14. Zaychenko, E.Yu., Severinovskaya, E.V., Dvoretskiy, A.I. \& Marenkov, O.N. (2014). Ecological hazard of radiation-chemical pollution of the Dnieper region. Ekolohiia i pryrodokorystuvannia, No. 18, pp. 84-94 [in Russian]. 
15. Inge-Vechtomov, S.G. (2010). Genetics with the basics of selection. Sankt-Peterburg: OOO "IzdatelstvoN-L" [in Russian].

16. Karpova, I.S. (2016). Discovery of mutagenic action of DNA in the light of lateral genomics. Faktory eksperymentalnoi evoliutsii orhanizmiv, No. 19, pp. 247-251 [in Russian].

17. Kunakh, V.A. (2013). Mobile genetic elements and plasticity of the plant genome. Kyiv: Lohos [in Ukrainian].

18. Litvyakov, N.V., Freydin, M.B., Halyuzova, M.V., Cazonov, A., Vasileva, E.O., Albah, E.N., Isubakova, D.S., Blinov, A.P., Rodionova, V.I., Kutko, A.A., Karpov, A.B. \& Tahauov, R.M. (2014). The frequency and spectrum of cytogenetic disorders in workers of the Siberian Chemical Combine. Radiation biology. Radioecology, 54, No. 3. pp. $283-$ 296 [in Russian]. https://doi.org/10.7868/S0869803113020069

19. Lobashev, M.E. (1947). Physiological (paranecrotic) hypothesis of the mutation process. Vestnik Leningradskogo gosudarstvennogo universiteta, No. 8, pp. 10-29 [in Russian].

20. Mihaylov, V.F., Mazurik, V.K., Burlakova, E.B., Ushenkova, L.N. \& Raeva, N.F. (2005). Molecular manifestations of radiation-induced genomic instability: the possibility of chemical modification.Radiation biology. Radioecology, 45, No. 5, pp. 561-570 [in Russian].

21. Morgun, V.V. \& Larchenko, K.A. (2006). Genetic effects of exogenous DNA when interacting with the genome of higher plants. Fiziologiya i biohimiya kulturnyih rasteniy, 38, No. 2, pp. 102-109 [in Ukrainian].

22. Nasonov, D.N. \& Aleksandrov, V. Ya. (1940). The reaction of living matter to external influences. The denaturation theory of damage and irritation. Moskva: Akademiya nauk SSSR [in Russian].

23. Patrushev, L.I. \& Minkevich, I.G. (2006). Non-coding sequences of the eukaryotic genome create an additional level of gene protection against chemical mutagens. Bioorganicheskaya himiya, 32, No. 4, pp. 408-413 [in Russian].

24. Serkiz, Ya.I. (1995). Long-term effects, incidence and life expectancy. Chernobyl disaster. Kyiv: Naukova dumka [in Russian].

25. Stroeva, O.G. (2012). The mechanism of chemical mutagenesis in the light of the microgenetic concept I.A. Rapoport. Induced mutagenesis in plant breeding (pp. 6-12), Bila Tserkva [in Ukrainian].

26. Syicheva, L.P. (2007). Biological significance, determination criteria and limits of variation of the full range of karyological parameters in assessing the cytogenetic status of a person. Meditsinskaya genetika, 6, No. 11, pp. 3-11 [in Russian].

27. Syicheva, L.P., Zhurkov, V.S. \& Rahmanin, Yu.A. (2013). Actual problems of genetic toxicology. Genetics, 49, No. 3, pp. 293-302 [in Russian].

28. Timofeev-Ressovsky, N.V. (2009). Selected works. Moskva: Nauka [in Russian].

29. Ulyanenko, S.E., Potetnya, V.I., Koryakin, S.N., Lyichagin, A.A., Koryakina, E.V., Solovev, A.N., Beketov, E.E. \& Isaeva, E.V. (2016, November).Settlement and experimental modeling of radiobiological effects at the molecular genetic level when exposed to radiation of different quality.International Scientific Conference Actual problems of radiobiology and astrobiology. Genetic and epigenetic effects of ionizing radiation (pp. 65-67), Dubna [in Russian].

30. Hesin, R.B. (1984). Genome Inconsistency. Moskva: Nauka [in Russian].

31. Chernenkov, A.Yu., Fedorov, D.V., Kosareva, A.A., Kozhina, T.N. \& Korolev, V.G. (2014). Change in the frequencies of spontaneous mutagenesis with combinations of the hsm3 and hsm6 mutations with the rad52 mutation in Saccharomyces cerevisiae yeast cells. Genetics, 50, No. 2, pp. 243-245 [in Russian].

32. Shevchenko, V.A. \& Snigireva, G.P. (2006). Significance of cytogenetic examination to assess the consequences of the Chernobyl disaster. Radiation biology. Radioecology, 46, No. 2, pp. 133-139 [in Russian].

33. Eyges, N.S. (2013). The historical role of Joseph Abramovich Rapoport in genetics. Continuation of research using the method of chemical mutagenesis. Vavilovskiy zhurnal genetiki I selektsii, 17, No. 1, pp. 162-172 [in Russian].

34. Eygest, N.S., Volchenko, G.A., Vaysfeld, L.I. \& Volchenko, S.G. (2011). Adaptive properties of winter wheat obtained by methods of hereditary and non-hereditary variability. Sovremennyiy mir, priroda i chelovek, 2, No. 1, pp. 55-58 [in Russian].

35. Yakymchuk, R.A. (2019). Long-term genetic effects of radiation on organisms. The Bulletin of Kharkiv national agrarian university. Series Biology, 47, No. 2, pp. 6-22 [in Ukrainian]. 
36. Yakymchuk, R.A. \& Morhun, V.V. (2015). Cytogenetic evaluation of the spontaneous level of winter wheat mutations in different ecological and geographical regions of Ukraine. Fiziol. rast. genet., 47, No. 2, pp. 126-135 [in Ukrainian].

37. Basu, S., Je, G. \& Kim, Y. S. (2015). Transcriptional mutagenesis by 8-oxodG in alphasynuclein aggregation and the pathogenesis of Parkinson's disease. Experimental \& Molecular Medicine, 47, p. 179. https://doi.org/10.1038/emm.2015.54

38. Bernstein, C., Prasad, A.R. \& Nfonsam, V. (2013). DNA damage, DNA repair and cancer. New Research Directions in DNA Repair. Publisher: InTech.

39. Boiteux, S. \& Guillet, M. (2004). Abasic sites in DNA: repair and biological consequences in Saccharomyces cerevisiae. DNA Repair, 3, No. 1, pp. 1-12.

40. Breysse, P.N. (Ed.) (2005). Toxicological profile for lead. Agency for toxic substances and disease registry division of toxicology and environmental medicine. Atlanta.

41. Bulathsinghala, A.T. \& Shaw, I.C. (2013). The toxic chemistry of methyl bromide. Human \& Experimental Toxicology, 33, No. 1, pp. 81-91. https://doi.org/10.1177/ 0960327113493299

42. Chernenkov, A., Fedorov, D., Kosareva, A., Kozhina, T., Evstiukhina, T., Peshekhonov, V. \& Korolev, V. (2013). The role of Saccharomyces cerevisiae HSM3 and HSM6 genes in DNA repair, mutagenesis and chromatin modifications. The FEBS Journal, 280, No. 1 , p. 65 .

43. Dexheimer, T.S. (2013). DNA repair pathways and mechanisms. DNA Repair of Cancer Stem Cells, Springer Netherlands.

44. Donbak, L., Celik, M., Demirhan, I. \& Nagas, S. (2007). Genotoxic damage in Maras powder consumers from kahramanmaras province of Turkey. Genetics, 43, No. 5, pp. 636637.

45. Fonseca Guerra, C., Bickelhaupt, F.M., Saha, S. \& Wang, F. (2006). Adenine tautomers: relative stabilities, ionization energies, and mismatch with cytosine. The Journal of Physical Chemistry, 110, No. 11, pp. 4012-4020.

46. Furmanchuk, A., Isayev, O., Gorb, L., Shishkin, O.V., Hovorun, D.M. \& Leszczynski, J. (2011). Novel view on the mechanism of water-assisted proton transfer in the DNA bases: Bulk water hydration. Physical Chemistry Chemical Physics, 13, No. 10, pp. 43114317. https://doi.org/10.1039/c0cp02177f

47. Keeling, P.J. \& Palmer, J.D. (2008). Horizontal gene transfer in eukaryotic evolution. Nature Reviews Genetics, 9, pp. 605-618. https://doi.org/10.1038/nrg2386

48. Kennard, O. (1985). Structural studies of DNA fragments: the G.T wobble base pair in A, B and Z DNA; the G.A base pair in BDNA. Journal of Biomolecular Structure and Dynamics, 3, No. 2, pp. 205-225.

49. Lindahl, T. \& Andersson, A. (1972). Rate of chain breakage at apurinic sites in doublestranded deoxyribonucleic acid. Biochemistry, 11, No. 19, pp. 3618-3623.

50. Lynch, M. (2016). Mutation and humanexceptionalism: our future genetic load. Genetics, 202, pp. 869-875. https://doi.org/10.1534/genetics.115.180471

51. Morgun, V.V. \& Yakymchuk, R.A. (2018). Cytogenetic anomalies of winter wheat cells, induced by chemical contamination of the territory of Kalush industrial district. Regulatory Mechanisms in Biosystems, 9, No. 3, pp. 446-452. https://doi.org/ $10.15421 / 021867$

52. Natarajan, A.T., Berni, A., Marimuthu, K.M. \& Palitti, F. (2008). The type and yield of ionizing radiation induced chromosomal aberrations depend on the efficiency of different DSB repair pathways in mammalian cells. Mutation Research, 642, pp. 80-85. https://doi.org/10.1016/j.mrfmmm.2008.05.002

53. Nelson, H.H., Marsit, C.J. \& Kelsey, K.T. (2011). Global methylation in exposure biology and translational medical science. Environmental Health Perspectives, 119, No. 11, pp. 1528-1533. https://doi.org/10.1289/ehp.1103423

54. Oladosu, Y., Rafii, M.Y., Abdullah, N., Hussind, G., Ramlie, A., Rahim, H. A., Miaha, G. \& Usmana, M. (2016). Principle and application of plant mutagenesis in crop improvement: a review. Biotechnology \& Biotechnological Equipment, 30, No. 1, pp. 116. https://doi.org/10.1080/13102818.2015.1087333

55. Pierce, B.A. (2012). Genetics: A conceptual approach fourth edition. New York: W.H. Freeman.

56. Rodin, S.N. \& Riggs, A.D. (2003). Epigenetic silencing may and evolution by gene duplication. Journal of Molecular Evolution, 56, pp. 718-729. 
57. Topal, M.D. \& Fresco, J.R. (1976). Complementary base pairing and the origin of substitution mutations. Nature, 263, No. 5575, pp. 285-289.

58. Venken, K.J.T., \& Bellen, H.J. (2014). Chemical mutagens, transposons, and transgenes to interrogate gene function in Drosophila melanogaster. Methods, 68, No. 1, pp. 15-28. https://doi.org/10.1016/j.ymeth.2014.02.025

59. Yakymchuk, R.A. (2018). Cytogenetic activity of radionuclide contamination of water reservoirs of the alienation zone of Chornobyl NPP. Regulatory Mechanisms in Biosystems, 9, No. 2, pp. 189-197. https://doi.org/10.15421/021828

60. Yakymchuk, R.A. (2015). Cytogenetic after-effects of mutagen soil contamination with emissions of Burshtynska thermal power station. In Opalko, A. I. (ed.). Ecological consequences of increasing crop productivity. Plant breeding and biotic diversity (pp. 217227), Toronto; New Jersey: Apple Academic Press.

61. Yakymchuk, R.A. (2018). Cytogenetic disorders in Triticum aestivum L. cells affected by radionuclide contamination of water reservoirs in the alienation zone of Chornobyl NPP. Biopolymers and Cell, 34, No. 2, pp. 97-106. http://doi.org/10.7124/bc.000974

Received 18.10.2019

\title{
ОСОБЛИВОСТІ МЕХАНІЗЗМІВ СПОНТАННОГО ТА ЇНДУКОВАНОГО ІІОНІЗУВАЛЬНИМ ВИПРОМІНЮВАННЯМ ІІ ХІМІЧНИМИ ЧИННИКАМИ МУТАГЕНЕЗУ
}

\author{
В.В. Моргун ${ }^{1}$, Р.А. Якимчук ${ }^{1}$, І.В. Азізов ${ }^{2}$ \\ ${ }^{1}$ Їнститут фізіології рослин і генетики Національної академії наук України, Київ \\ ${ }^{2} \dot{\mathbf{I}}$ нститут молекулярної біології та біотехнологій Національної академії наук \\ Азербайджану, Баку
}

В статті узагальнено літературні дані про особливості механізмів спонтанного та індукованого мутагенезу. Їх вивчення дасть змогу розширити уявлення про роль мутацій у видоутворенні та еволюції органічного світу, а також передбачати інтенсивність і характер мутаційних змін у природних популяціях техногенно забруднених територій. Наголошується на визнанні трьох різних підходів щодо природи виникнення спонтанних точкових мутацій: таутомерна гіпотеза; іонізаційний механізм; підхід, який оперує неправильними парами основ ДНК в основній, канонічній таутомерній формі як джерелом мутацій. Зазначається, що саме фізико-хімічна властивість неправильних пар основ ДНК із Уотсон-Криківською і вобл-архітектурами, що пов'язана з контролюванням високостабільними перехідними парами, є новим ключем до розуміння природи спонтанного точкового мутагенезу. Обговорюються умови, які забезпечують реалізацію первинних пошкоджень ДНК в мутації. Серед них особлива роль відводиться ефективності репараційних процесів, що виявляється різною за неоднакових дозових навантажень мутагенів. Наведено докази зростання частоти мутацій внаслідок різких змін умов навколишнього середовища, які викликають активування нуклеотидних послідовностей, що не кодують білки, мобільних генетичних елементів різних класів та послідовностей, що відповідають малим РНК. Описано механізми індукованого мутагенезу за впливу високих і низьких доз іонізувального випромінення і хімічних мутагенів. Показано, що індуковані опроміненням із малою лінійною передачею енергії немішенні ефекти пов'язані з утворенням генотоксичних сполук та ослабленням інтенсивності процесів репарації ДНК. Хімічні мутагенні чинники індукують зростання частоти і спектра порушень молекули ДНК, що зумовлено високою спорідненістю хімічних мутагенів зі структурами генетичного матеріалу. Хімічні мутагени за низьких і помірних концентрацій здатні індукувати високу частоту точкових мутацій та низький рівень хромосомних перебудов; за високих концентрацій виявляють радіоміметичні властивості. Подальше пізнання механізмів спонтанного мутагенезу і генетичної відповіді біологічної системи на зовнішні стреси уможливить пошук нових мутагенних чинників, які б викликали високий рівень керованої се- 
лекціонером мінливості організмів, та виявлення шляхів уникнення їхніх негативних генетичних наслідків у разі потрапляння в навколишнє середовище.

Ключові слова: механізми мутагенезу, спонтанні та індуковані мутації, системи репарації, первинні пошкодження ДНК, немішенні ефекти.

\section{ОСОБЕННОСТИ МЕХАНИЗМОВ СПОНТАННОГО И ИНДУЦИРОВАННОГО ИОНИЗИРУЮЩИМ ИЗЛУЧЕНИЕМ И ХИМИЧЕСКИМИ ФАКТОРАМИ МУТАГЕНЕЗА}

\section{В.В. Моргун ${ }^{1}$, Р.А. Якимчук ${ }^{1}$, И.В. Азизов ${ }^{2}$}

${ }^{1}$ Институт физиологии растений и генетики Национальной академии наук Украины, Киев

${ }^{2}$ Институт молекулярной биологии и биотехнологий Национальной академии наук Азербайджана, Баку

В статье обобщены литературные данные об особенностях механизмов спонтанного и индуцированного мутагенеза. Их изучение позволит расширить представления о роли мутаций в видообразовании и эволюции организмов, а также предвидеть интенсивность и характер мутационных изменений в природных популяциях на техногенно загрязненных территориях. Акцентируется внимание на признании трех разных подходов относительно природы возникновения спонтанных точечных мутаций: таутомерная гипотеза; ионизационный механизм; подход, оперирующий неправильными парами оснований ДНК в основной, канонической таутомерной форме как источником мутаций. Отмечается, что именно физико-химическое свойство неправильных пар оснований ДНК с Утсон-Криковской и вобл-архитектурами, связанное с контролированием высокостабильными переходными парами, является новым ключом к пониманию природы спонтанного точечного мутагенеза. Обсуждаются условия, обеспечивающие реализацию первичных повреждений ДНК в мутации. Среди них особая роль отводится эффективности репарационных процессов, которая оказывается разной при неодинаковых дозовых нагрузках мутагенов. Приведены доказательства возрастания частоты мутаций вследствие резких изменений условий окружающей среды, которые вызывают активирование некодирующих белки нуклеотидных последовательностей, мобильных генетических элементов разных классов и соответствующих малым РНК последовательностей. Описываются механизмы индуцированного мутагенеза в условиях влияния высоких и низких доз ионизирующего излучения и химических мутагенов. Показано, что индуцированные облучением с малой линейной передачей энергии немишенные эффекты связаны с образованием генотоксических соединений и ослаблением интенсивности процессов репарации ДНК. Химические мутагенные факторы индуцируют возрастание частоты и спектра нарушений молекулы ДНК, что обусловлено высоким сродством химических мутагенов со структурами генетического материала. Химические мутагены при низких и умеренных концентрациях способны индуцировать высокую частоту точечных мутаций и низкий уровень хромосомных перестроек; при высоких концентрациях - проявляют радиомиметические свойства. Дальнейшее познание механизмов спонтанного мутагенеза и генетического ответа биологической системы на внешние стрессы позволит осуществлять поиск новых мутагенных факторов, которые вызывали бы высокий уровень управляемой селекционером изменчивости организмов, и определять пути избежания их негативных генетических последствий в случае попадания в окружающую среду.

Ключевые слова: механизмы мутагенеза, спонтанные и индуцированные мутации, системы репарации, первичные повреждения ДНК, немишенные эффекты. 